\title{
Are Micro and Macro Labor Supply Elasticities Consistent? A Review of Evidence on the Intensive and Extensive Margins
}

\section{Citation}

Chetty, Raj, Adam Guren, Day Manoli, and Andrea Weber. 2011. Are Micro and Macro Labor Supply Elasticities Consistent? A Review of Evidence on the Intensive and Extensive Margins. American Economic Review 101(3): 471-475.

\section{Published Version}

doi:10.1257/aer.101.3.471

\section{Permanent link}

http://nrs.harvard.edu/urn-3:HUL.InstRepos:11878970

\section{Terms of Use}

This article was downloaded from Harvard University's DASH repository, and is made available under the terms and conditions applicable to Other Posted Material, as set forth at http:// nrs.harvard.edu/urn-3:HUL.InstRepos:dash.current.terms-of-use\#LAA

\section{Share Your Story}

The Harvard community has made this article openly available.

Please share how this access benefits you. Submit a story.

\section{Accessibility}




\title{
Are Micro and Macro Labor Supply Elasticities Consistent? A Review of Evidence on the Intensive and Extensive Margins
}

\author{
By Raj Chetty, Adam Guren, Day Manoli, and Andrea Weber*
}

Macroeconomic models of fluctuations in hours of work over the business cycle or across countries imply much larger labor supply elasticities than microeconometric estimates of hours elasticities. Understanding this divergence is critical for questions ranging from the sources of business cycles to the impacts of tax policy. Since the discrepancy between micro and macro elasticities was recognized in the 1980s, economists have made significant advances in understanding labor supply. For instance, macroeconomists have developed models of indivisible labor in which extensive-margin responses make aggregate-hours elasticities larger than intensive-margin elasticities (Richard Rogerson 1988, Gary D. Hansen 1985, Lars Ljungqvist and Thomas J. Sargent 2006). Meanwhile, microeconomists have amassed a large body of evidence on intensive (hours conditional on employment) and extensive (participation) labor supply elasticities.

The goal of this paper is to evaluate whether state-of-the-art macro models featuring indivisible labor are consistent with modern quasi-experimental micro evidence. To do so, we consider evidence on both the intensive and extensive margins. Although macro models are now calibrated to match micro estimates of intensive mar-

* Chetty: Harvard University Department of Economics and NBER, 1805 Cambridge St., Cambridge, MA 02138 (email: chetty@fas.harvard.edu). Guren: Harvard University Department of Economics, 1805 Cambridge St., Cambridge, MA 02138 (email: guren@fas.harvard.edu). Manoli: UCLA Department of Economics, RAND, and NBER, 8283 Bunche Hall Box 951477, Los Angeles, CA 90095 (email: dsmanoli@econ.ucla.edu). Weber: University of Mannheim Department of Economics, L7, 3-5, 68131, Mannheim, Germany (email: a.weber@uni-mannheim.de). Thanks to Peter Ganong and Jessica Laird for outstanding research assistance and Richard Blundell, Greg Bruich, David Card, John Friedman, Bob Hall, Greg Mankiw, Richard Rogerson, Robert Shimer, and Danny Yagan for helpful comments. gin elasticities, the extensive margin elasticity is often treated as a free parameter that is calibrated purely to match macroeconomic moments. But micro estimates are equally useful in calibrating extensive margin responses: the marginal density of the reservation wage distribution that determines the impacts of macroeconomic variation on employment also determines the impacts of quasi-experiments such as tax policy changes on employment rates.

We find that micro estimates are consistent with macro estimates of the steadystate (Hicksian) elasticities relevant for cross-country comparisons on both the extensive and intensive margins. However, micro estimates of intertemporal substitution (Frisch) elasticities are an order of magnitude smaller than the values needed to explain business cycle fluctuations in aggregate hours by preferences. Quasi-experimental estimates of extensive margin intertemporal substitution elasticities are around 0.25 , whereas leading pure equilibrium macro models imply intertemporal substitution extensive margin elasticities around 2. Hence, the key puzzle to be resolved is why employment rates fluctuate so much over the business cycle relative to what one would predict based on the impacts of tax changes on employment rates - that is, why micro and macro estimates of the Frisch extensive margin elasticity are so different.

\section{Terminology}

It is helpful to establish conventions about terminology given the various elasticity concepts used in the micro and macro literatures. We distinguish between elasticities based on the margin of response (extensive vs. intensive) and the timing of response (intertemporal substitution vs. steady state). There are four elasticities of interest: steady- 
Table 1-Micro vs. Macro Labor Supply Elasticities

\begin{tabular}{ll|cc|c}
\hline \hline & & Intensive Margin & Extensive Margin & Aggregate Hours \\
\hline Steady State & micro & 0.30 & 0.26 & 0.56 \\
(Hicksian) & macro & 0.38 & 0.14 & 0.51 \\
\hline Intertemporal & micro & 0.54 & 0.28 & 0.82 \\
Substitution (Frisch) & macro & {$[0.54]$} & {$[2.30]$} & 2.84 \\
\hline \hline
\end{tabular}

Note: Each cell shows a point estimate of the relevant elasticity based on meta analyses of existing micro and macro evidence. Micro estimates are identified from quasi-experimental studies; macro estimates are identified from crosscountry variation in tax rates (steady state elasticities) and business cycle fluctuations (intertemporal substitution elasticities). The aggregate hours elasticity is the sum of the extensive and intensive elasticities. Macro studies do not always decompose intertemporal aggregate hours elasticities into extensive and intensive elasticities. Therefore, the estimates in brackets show the values implied by the macro aggregate hours elasticity if the intensive Frisch elasticity is chosen to match the micro estimate of 0.54 . Sources are described in the appendix.

state extensive, steady-state intensive, intertemporal extensive, and intertemporal intensive. We use the terms "micro" and "macro" elasticities to refer to the sources of variation used to estimate the elasticities. The elasticity of aggregate hours - the relevant parameter for calibrating a representative agent model - is the sum of the extensive and intensive margin elasticities, weighted by hours of work if individuals have heterogeneous preferences (Richard Blundell, Antoine Bozio, and Guy Laroque 2011).

The macro literature uses the term "macro elasticity" to refer to the Frisch elasticity of aggregate hours and the term "micro elasticity" to refer to the intensive-margin elasticity of hours conditional on employment (e.g. Edward Prescott 2004, Rogerson and Johanna Wallenius 2009). We use different terminology here for two reasons. First, the intensive-margin is no more "micro" than the extensive margin; both reflect household-level responses and both have been estimated using micro data. Second, although the Frisch elasticity is critical for understanding business cycle fluctuations, it is not relevant for evaluating the steady-state impacts of differences in taxes across countries. The Frisch (marginal utility constant) elasticity controls intertemporal substitution responses to temporary wage fluctuations, while the Hicksian (wealth constant) elasticity controls steadystate responses and the welfare cost of taxation. This distinction is quite important in practice. Prescott (2004) reports that cross- country differences in aggregate hours imply an elasticity of 3 in a representative-agent model, whereas Steven J. Davis and Magnus Henrekson (2005) estimate an elasticity of 0.33 using similar data. The difference is almost entirely because Prescott reports a Frisch elasticity whereas Davis and Henrekson report a Hicksian elasticity.

\section{Comparing Micro and Macro Estimates}

We summarize the micro and macro evidence on the extensive and intensive margins in Table 1. The rows of consider steadystate (Hicksian) vs. intertemporal substitution (Frisch) elasticities, while the columns compare intensive margin (hours conditional on employment) and extensive margin (participation) elasticities. Within each of the four cells, we report micro and macro estimates of the elasticity based on (unweighted) means of existing studies. We also calculate aggregate hours elasticities by summing the extensive and intensive elasticities. ${ }^{1}$

There are wide confidence intervals associated with each of the point estimates in Table 1, as well as methodological disputes about the validity of some of the studies. Therefore, the estimates should be used to gauge orders of magnitude: differences of 0.1 between elasticity estimates could be due to

\footnotetext{
${ }^{1}$ This calculation requires that preferences are homogenous. If some groups work few hours and also have higher extensive elasticities, as suggested by existing evidence, this will yield an upper bound on the aggregate hours elasticity (Blundell, Bozio, and Laroque 2011).
} 
noise or choice of specification, while differences of 1 reflect fundamental discrepancies.

Steady-State Elasticities. On the extensive margin, Chetty et al. (2011b) conduct a meta-analysis of quasi-experimental studies that span a broad range of countries, demographic groups, time periods, and sources of variation. Every extensive margin steady state elasticity Chetty et al. consider is below 0.45 . We use their mean estimate of 0.26 for the micro extensive margin steady-state elasticity.

On the intensive margin, Chetty (2009) presents a meta-analysis of micro estimates of Hicksian elasticities and reports a mean value of 0.12 (Chetty 2009, Table 1, unweighted mean of Panels A and B). However, Chetty and Chetty et al. (2011a) argue that these elasticities are significantly attenuated by optimization frictions: the small tax changes used to identify micro elasticities do not generate substantial changes in hours because the costs of adjusting hours outweigh the second-order benefits of reoptimization. Chetty (2009) develops a bounding method of recovering the underlying structural elasticity relevant for evaluating the steady-state impacts of taxes. Pooling the twenty studies he analyzes, he obtains a preferred estimate of the structural intensive margin Hicksian elasticity of $0.3 .^{2}$

Macro steady-state estimates are obtained from comparisons across countries with different tax regimes. On the extensive margin, Steven Nickell (2003) and Davis and Henrekson (2005) find steady-state elasticities of 0.14 on average by comparing employment rates across countries. On the intensive margin, analogous comparisons of work hours across OECD countries by Prescott (2004) and Davis and Henrekson (2005) imply a mean steady-state elasticity of 0.38 . We conclude that micro and macro estimates

\footnotetext{
${ }^{2}$ Our proposed elasticities may appear to contradict the common view that tax changes have smaller effects on the intensive margin than extensive margin. Chetty (2009) shows that frictions attenuate observed extensive margin elasticities much less than intensive margin elasticities because the utility gains from reoptimizing are first-order on the extensive margin and second-order on the intensive margin. Consequently, the structural intensive margin elasticity is larger than the structural extensive margin elasticity.
}

of steady-state aggregate hours elasticities match once one accounts for extensive margin responses and the attenuation of intensive margin micro elasticities due to optimization frictions.

Intertemporal Substitution Elasticities. On the extensive margin, our micro estimate of 0.28 comes from Chetty et al.'s (2011b) meta-analysis of studies of intertemporal substitution, which examine the impacts of changes in retirement incentives or temporary tax reforms. On the intensive margin, there is less quasi-experimental evidence on intertemporal substitution elasticities. Marco Bianchi, Björn R. Gudmundsson, and Gylfi Zoega (2001) find an intensive-margin elasticity of 0.37 by studying a temporary tax change in Iceland (see Chetty (2009) for the elasticity calculation). Luigi Pistaferri (2003) reports a Frisch intensive elasticity of 0.7 using micro data on expectations about wages. The similarity between these estimates and our preferred estimate of the intensive Hicksian elasticity of 0.3 is not surprising. Chetty (2009) shows that the Frisch elasticity must be less than 0.61 given a Hicksian elasticity of 0.3 in a model with balanced growth and an elasticity of intertemporal substitution below 1. Hence, micro evidence suggests that Frisch and Hicksian elasticities are similar in magnitude.

Equilibrium macro models - in which fluctuations in hours are driven by preferences - identify intertemporal substitution labor supply elasticities from business cycle variation. Most macro studies calibrate representative agent models and therefore report only intertemporal elasticities of aggregate hours. The intertemporal aggregate hours elasticity required to match business cycle data is between 2.61 and 4 in real business cycle models (Jang-Ok Cho and Thomas F. Cooley 1994, Table 1; Robert G. King and Sergio T. Rebelo 1999, p975) and 1.92 in menu cost models (Frank Smets and Rafael Wouters 2007, Table 1A). The mean intertemporal aggregate hours elasticities implied by these three models is 2.84. Micro estimates imply a Frisch elasticity of aggregate hours of 0.82 , well below this value.

The few available decompositions of macro 
aggregate hours elasticities into extensive and intensive margins suggest that macro estimates are roughly in alignment with micro estimates on the intensive margin. Business cycle fluctuations in hours conditional on employment account for only $1 / 6$ of the fluctuations in aggregate hours at an annual level (James J. Heckman 1984). Given that elasticities of 4 fit the fluctuations in aggregate hours in real business cycle models, we infer that intensive Frisch elasticities around 0.66 match macro evidence in RBC models.

In contrast, macro evidence sharply contradicts micro estimates of the extensive intertemporal elasticity. The fact that employment fluctuations account for $5 / 6$ of the fluctuation in aggregate hours suggests that extensive elasticities above 3 would be needed to match the data in standard RBC models. If macro models with an extensive margin were calibrated to match an intensive intertemporal elasticity of 0.54 , they would require extensive intertemporal elasticities of $2.84-0.54=2.30$ on average to match aggregate hours fluctuations. This value is an order of magnitude larger than all of the micro estimates considered by Chetty et al. (2011b). Hence, extensive labor supply responses are not large enough to explain the large fluctuations in employment rates at business cycle frequencies. In the terminology of Ljungqvist and Sargent (2011), the micro data reveal that most individuals are at a corner in their employment decisions.

Macro models may not perfectly match micro evidence on the extensive margin because extensive margin elasticities vary with the distribution of reservation wages at the margin. While one may be reluctant to calibrate a macro model to match an extensive margin elasticity estimate from any single study, the fact that all fifteen quasiexperimental studies reviewed by Chetty et al (2011b) find elasticities less than 0.45 casts doubt upon macro models calibrated with extensive margin elasticities above 1 . Moreover, observable heterogeneity in elasticities reinforces the divergence between micro and macro evidence on intertemporal elasticities. While microeconomic evidence suggests that extensive margin elasticities are near zero for prime-age men, employ- ment rates fluctuate substantially over the business cycle even for this subgroup (Nir Jaimovich and Henry E. Siu 2009).

The importance of reconciling micro and macro evidence on both the intensive and extensive margins can be seen by simulating the impacts of quasi-experiments such as tax policy changes in macro models. Chetty et al. (2011b) use Rogerson and Wallenius' (2009) calibrated life cycle model to simulate the impacts of tax reforms studied in the micro literature on employment rates. The Rogerson and Wallenius model over-predicts the employment impacts of temporary tax changes that induce intertemporal substitution by an order of magnitude, but comes much closer to matching the steady-state impacts of permanent tax changes, mirroring the conclusions drawn above.

\section{Conclusion}

Based on our reading of the micro evidence, we recommend calibrating macro models to match Hicksian elasticities of 0.3 on the intensive and 0.25 on the extensive margin and Frisch elasticities of 0.5 on the intensive and 0.25 on the extensive margin. Hence, it would be reasonable to calibrate representative agent macro models to match a Frisch elasticity of aggregate hours of $0.75 .^{3}$ These elasticities are consistent with the observed differences in aggregate hours across countries with different tax systems. They also match the relatively small fluctuations in hours conditional on employment over the business cycle. The challenge is to formulate models that fit the large fluctuations in employment rates over the business cycle when calibrated to match an extensive margin labor supply elasticity of $0.25 .^{4}$ Even with indivisible labor, models that require a Frisch

\footnotetext{
${ }^{3}$ We suspect that this estimate is, if anything, biased upward for two reasons: (1) the mean extensive margin elasticity for the population as a whole is less than 0.25 as noted above and (2) publication bias may drive micro studies toward reporting higher elasticity estimates.

${ }^{4}$ One approach, pursued e.g. by Hall (2009), is to move away from models in which employment fluctuations are driven purely by worker preferences. Hall shows that a search and matching model can generate large fluctuations in employment rates over the business cycle without large extensive labor supply responses.
} 
elasticity of aggregate hours above 1 are inconsistent with micro evidence.

\section{APPENDIX: SOURCES OF ESTIMATES FOR TABLE 1}

This appendix describes how each of the values in Table 1 are calculated. With the exception of the Frisch aggregate hours macro elasticity, the aggregate hours elasticities are defined as the sums of the intensive and extensive margin elasticities.

Hicksian, extensive margin: The micro estimate is the mean of the estimates in Panel A of Table 1 in Chetty et al. (2011b). The macro estimate is computed by taking the mean of 0.13 from Davis and Henrekson (2005) and 0.14 from Nickell (2003). The elasticity from Davis and Henrekson is computed using the log difference in employment based on the slope coefficient in Table 3 (bottom panel, Sample C) and the sample means of labor force participation and tax rates in Table 1 for the corresponding sample. The elasticity from Nickell is computed using the average point estimate of 2 percent (reported on page 8 ) and the sample means of employment rates and tax rates from Tables 1 and 2 , respectively.

Hicksian, intensive margin: The micro estimate is the preferred estimate of the structural elasticity reported by Chetty (2009). The macro estimate is the mean of the values implied by Davis and Henrekson (2005) and Prescott (2004). The value from Davis and Henrekson (2005) is computed using log differences in annual hours per employed adult based on the slope coefficient in Table 3 (middle panel, Sample C) and the sample means of annual hours per employed person and tax rates in Table 1 for the corresponding sample. The value from Prescott (2004) comes from subtracting the Hicksian macro extensive margin elasticity (0.14) from the aggregate hours elasticity (0.70), which is estimated using a cross-sectional regression of $\log$ actual hours on $\log$ net-of-tax rates $(1-\tau)$ based on the pooled data from both periods reported by Prescott in Table 2 .

Frisch, intensive margin elasticities: the micro estimate is the unweighted mean of 0.70 in Table 2 from Pistaferri (2003) and 0.37 from Bianchi, Gudmundson, and Zoega
(2001), as reported in Chetty (2009). The macro value in brackets is set equal to the micro estimate.

Frisch, extensive margin: The micro estimate is the mean of the estimates in Panel B of Table 1 in Chetty et al. (2011b). The macro value in brackets is computed by subtracting the Frisch micro intensive margin elasticity from the Frisch aggregate hours macro elasticity.

Frisch, aggregate hours macro: The estimate is the mean of the aggregate (total hours) elasticities implied by three models of business cycles: (1) Cho and Cooley (1994): 2.61 from the sum of the intensive and extensive margin elasticities implied by the parameters in Table 2; (2) King and Rebelo (1999): 4 for representative agent RBC models, from page 975, and (3) Smets and Wouters (2007): 1.92 from Table 1A, Posterior Distribution, Mode.

\section{REFERENCES}

Bianchi, Marco, Björn R. Gudmundsson, and Gylfi Zoega. 2001. "Iceland's Natural Experiment in Supply-Side Economics." American Economic Review, 91(5): 1564-79.

Blundell, Richard, Antoine Bozio, and Guy Laroque. 2011. "Labour Supply and the Extensive Margin" Forthcoming, American Economic Review Papers and Proceedings.

Chetty, Raj. 2009. "Bounds on Elasticities with Optimization Frictions: A Synthesis of Micro and Macro Evidence on Labor Supply." NBER Working Paper 15616.

Chetty, Raj, John N. Friedman, Tore Olsen, and Luigi Pistaferri. 2011a. "Adjustment Costs, Firm Responses, and Micro vs. Macro Labor Supply Elasticities: Evidence from Danish Tax Records." Quarterly Journal of Economics, forthcoming.

Chetty, Raj, Adam Guren, Day Manoli, and Andrea Weber. 2011b. "Does Indivisible Labor Explain the Difference between Micro and Macro Elasticities? A Meta-Analysis of Extensive Margin Elasticities." NBER Working Paper. 
Cho, Jang-Ok, and Thomas F. Cooley. 1994. "Employment and Hours Over the Business Cycle." Journal of Economic Dynamics and Control, 18(2): 411-32.

Davis, Steven J., and Magnus Henrekson. 2005. "Tax Effects on Work Activity, Industry Mix and Shadow Economy Size: Evidence from Rich-Country Comparisons." In Labour Supply and Incentives to Work in Europe, ed. Ramón Gómez Salvador, Ana Lamo, Barbara Petrongolo, Melanie Ward, and Etienne Wasmer, 44-104. Northamption, MA: Edward Elgar Press.

Hall, Robert E. 2009. "Reconciling Cyclical Movements in the Marginal Value of Time and the Marginal Product of Labor." Journal of Political Economy, 117(2): 281-323.

Hansen, Gary D. 1985. "Indivisible Labor and the Business Cycle." Journal of Monetary Economics. 16(3): 309-327.

Heckman, James J. 1984. "Comments on the Ashenfelter and Kydland Papers." Carnegie-Rochester Conference Series on Public Policy, 21: 209-24.

Jaimovich, Nir, and Henry E. Siu. 2009. "The Young, the Old, and the Restless: Demographics and Business Cycle Volatility" American Economic Review, 99(3): 804-26.

King, Robert G., and Sergio T. Rebelo. 1999. "Resuscitating Real Business Cycles." In Handbook of Macroeconomics, ed. John B. Taylor and Michael Woodford, 927-1007. Amsterdam: North-Holland.

Ljungqvist, Lars, and Thomas J. Sargent. 2006. "Do Taxes Explain European Employment? Indivisible Labor, Human Capital, Lotteries, and Savings." In NBER Macroeconomics Annual 2006, ed. Daron Acemoglu, Kenneth Rogoff, and Michael Woodford, 181-246. Cambridge, MA: MIT Press.

Ljungqvist, Lars, and Thomas J. Sargent. 2011. "A Labor Supply Elasticity Accord?" Forthcoming, American Economic Review Papers and Proceedings.
Nickell, Steven. 2003. "Employment and Taxes." CESifo Working Paper 1109.

Pistaferri, Luigi. 2003. "Anticipated and Unanticipated Wage Changes, Wage Risk, and Intertemporal Labor Supply." Journal of Labor Economics, 21(3): 729-54.

Prescott, Edward. 2004. "Why Do Americans Work So Much More Than Europeans?" Federal Reserve Bank of Minneapolis Quarterly Review, 28(1): 2-13.

Rogerson, Richard. 1988. "Indivisible Labor, Lotteries and Equilibrium." Journal of Monetary Economics, 21(1): 3-16.

Rogerson, Richard, and Johanna Wallenius. 2009. "Micro and Macro Elasticities in a Life Cycle Model with Taxes." Journal of Economic Theory, 144(6): 2277-92.

Smets, Frank, and Rafael Wouters. 2007. "Shocks and Frictions in US Business Cycle: A Bayesian DSGE Approach." American Economic Review. 97(3): 586-606. 